\title{
Transfer of PUFA fatty acid protected and carnitin precursor on the ration of chemical composition of milk dairy goat
}

\author{
Sudibya, Sutrisno Hadi Purnomo
}

Department of Animal Science, Faculty Agriculture, Sebelas Maret University, Surakarta, Indonesia; sutrisno_hadi@uns.ac.id

Received 11 March 2013; revised 30 April 2013; accepted 15 May 2013

Copyright (C) 2013 Sudibya, Sutrisno Hadi Purnomo. This is an open access article distributed under the Creative Commons Attribution License, which permits unrestricted use, distribution, and reproduction in any medium, provided the original work is properly cited.

\begin{abstract}
The experiment was conducted to investigate the effect of transfer of PUFA protected and carnitin precursor on the ration of chemical composition of milk dairy goat. In total, 10 female dairy goats of 2 - 4 years old Peranakan Etawah (PE) with body weight of 25 - $45 \mathrm{~kg}$ were used in this experiment. The feed material included a basal diet (control) based on yellow corn, rice bran, soya bean meal, coconut meal, tuna fish oil and lemuru fish oil. The method of the research was experimental in vivo using Randomized Completely Block Design (RCBD). There were 5 treatments in each experiment and 2 replications. The treatment consisted of $P_{0}=$ control ration, $P_{1}=P_{0}+200 \mathrm{ppm}$ L-carnitine on the ration, $P_{2}=P_{1}+$ soya bean oil, $P_{3}=P_{1}+$ protected tuna fish oil $5 \mathrm{ml}$ or equal with $4 \%$ in the ration, and $P_{4}=P_{1}+$ protected lemuru fish oil 5 $\mathrm{ml}$ or equal with $4 \%$ in the ration. The measured variable is chemical composition of milk dairy goat. The results of variance analysis showed that the effect of transfer of PUFA fatty acid in the rations contained $200 \mathrm{ppm}$ L-carnitine significantly $(P<0.01)$ affecting the chemical composition of milk dairy goat. This research concluded that the transfer of PUFA fatty acid protected in the ration containing $200 \mathrm{ppm}$ L-carnitine can decrease milk cholesterol from $0.19 \%$ to $0.12 \%$, LDL from 33.34 to $23.13 \mathrm{mg} / \mathrm{dl}$, lipid from $4.53 \%$ to $3.76 \%$ then to increase omega-3 fatty acid from $1.00 \%$ to $3.94 \%$, omega- 6 fatty acid from $1.46 \%$ to $18.80 \%$.
\end{abstract}

Keywords: Milk Dairy Goat; L-Carnitine; PUFA Protected Fatty Acid; Chemical Composition

\section{INTRODUCTION}

The purpose of the study is to make feed formula of dairy goat. The second purpose is to examine the content of omega-3 fatty acids and low cholesterol through supplementation of L-carnitine and soap extract of tuna fish oil and lemuru fish oil protected. The objective of this study is to reduce milk cholesterol and increase omega-3 fatty acids in the milk. The effort to increase the content of omega-3 fatty acids and low cholesterol in the goat milk is a breakthrough to produce healthy animal products. These products can be made by manipulating the soap supplementation protected with extracts containing omega-3 fatty acids through the ration that is mixed in rations that use of L-carnitine. Supplementation L-carnitine can decrease cholesterol meat, increase nutrient digestibility, increase conversion ratio and decrease carcass lipid [1]. Research on milk products with high omega-3 fatty acids has not been revealed, but as a foothold in beef, has been done by Sudibya et al. [2] which continued in year 2006 [3], in year 2007 [4] on goat and in year 2010 on milk dairy cow with the result very significant. The researcher assumes if the method is applied on the dairy goat, its impact will be the same because it is still included in ruminant animal. Sources of omega-3 fatty acids often found in marine fish, mainly lemuru, tuna and shark. Lemuru fish when pressed will generate a lot of fish oil containing omega-3 fatty acids especially EPA (eicosapentaenoic) $34.17 \%$ and DHA (docosahexaenoic) around $17.40 \%$ and fat content $6 \%$ and TDN $182 \mathrm{kcal} / \mathrm{kg}$ fish oil, while tuna fish when pressed will generate a lot of fish oil containing omega-3 fatty acids especially EPA (eicosapentaenoic) $33.6 \%$ to $44.85 \%$ and DHA (docosahexaenoic) around $14.64 \%$ and $5.8 \%$ fat and $178 \mathrm{kcal}$ $\mathrm{TDN} / \mathrm{kg}$ by Sudibya et al. [2,4]. Based on the differences in content of two fish, therefore, it needs to be examined for comparison. Fish oil is a source of fat. Manipula- 
tions of fat metabolism in the rumen are intended to produce two of the first particle control antimicrobial effects of fatty acids to minimize disturbance of rumen fermentation, so that the highest fat level can be included in the diet, secondly to control biohidrogenasi to increase the absorption of desired fatty acids to improve the nutriational quality of livestock products [5]. Fish oil supplementation in the diet should be with a particular dose so as not to disrupt the activity of rumen microorganisms. Cherian and Sim [6] state that the addition of fish oils in ruminant feed should not exceed $6 \%-7 \%$ of ration dry matter as it will affect rumen fermentation microorganisms. Sudibya et al. [7] state that the functions of omega-3 fatty acids in decreasing cholesterol levels in two ways, namely 1) stimulate the excretion of cholesterol through the bile from the liver into the intestine, and 2) stimulate the catabolism of HDL cholesterol by the liver back into bile acids and not regenerate again but exclude with excreta. Bufallo meat and beef are usually consumed by humans in a state of cooked so we need organoleptic (taste, odor and color) and the content of omega-3 fatty acids as well as fat oxidation products with peroxide levels and the levels of malonaldehyde with TBA test (thiobarbiturat acid) whether or not changed.

\section{MATERIALS AND METHODS}

\subsection{Time and Place of Research}

This research is experimental design conducted in the area Gledeg village, Karanganom District, Klaten Regency. The laboratory analysis conducted in Science Laboratory of Bogor Institute of Agriculture, Chemistry Laboratory of Gadjah Mada University and Laboratory of Agriculture Technology and the Laboratory of Feed Nutrition, Department of Animal Husbandry of Sebelas Maret University, Surakarta. The research was conducted during ten months from March to December 2012.

\subsection{Materials}

Phase I: Fatty acid soap protected. Extracts of omega-3 fatty acids derived from tuna fish oil and lemuru fish oil. Phase II: dairy goat lactation 10 females with weight 25 - $55 \mathrm{~kg}$, soap protected—containing tuna fish oil and lemuru fish oil, Cages tobong one unit for the 10 goat milk with length $=25 \mathrm{~m}$ and width of $8 \mathrm{~m}$ and individual cages 10 units and each unit contains one goat milk of production. Basic ration is in accordance with the treatment.

\subsection{Methods}

\subsubsection{Omega-3 Fatty Acids Extraction}

Protected fat products are made through a combination of process saponification and incapsulation lemuru fish oil and tuna oil using $10 \% \mathrm{NaOH}, 10 \%$ starch and saturated $\mathrm{CaCl}_{2}$ solution. Saponification and incapsulation done by lemuru fish oil, tuna fish is heated at a temperature of $60-800^{\circ} \mathrm{C}$ for 10 minutes and then mixed with $10 \% \mathrm{NaOH}$ solution with stirring and $10 \%$ starch solution is added to form a paste of clay. Clumps are settling for one night in order to harden. Clumps of crystallized soap obtained by soaking with saturated $\mathrm{CaCl}_{2}$ solution for 2 hours. Comparison of the 1:2:1 material. Fatty acid soap crystals formed was filtered and then pressed and then dried in the oven or in the sun. Fatty acid soap crystals that have been dried in the digestibility trials and the resistance to the process of dehydrogenation by rumen microbes and its influence on rumen cellulolytic activity with insaco method.

\subsubsection{Statistical Analyses}

The study was conducted as a Randomized Completely Block Design (RCBD) with 5 dietary treatments namely $\mathrm{P}_{0}=$ Control ration, $\mathrm{P}_{1}=\mathrm{P}_{0}+\mathrm{L}$-carnitine 250 ppm in the ration, $\mathrm{P}_{2}=\mathrm{P}_{1}+$ oil soya bean meal $4 \%$ in the ration, $\mathrm{P}_{3}=\mathrm{P}_{1}+$ soap protected fish oil tuna $4 \%$ in the ration, $\mathrm{P}_{4}=\mathrm{P}_{1}+$ soap protected lemuru fish oil $4 \%$ in the ration, and using 2 blocks as replications. Each unit contains 1 block of goat milk. The following linier model was considered $Y_{i j}=\mu+\rho+\alpha i+\varepsilon_{i j}$ where $Y_{i j}=J^{\text {th }}$ measurement in $i^{\text {th }}$ treatments on $\mathrm{j}^{\text {th }}$ animal, $\mu=$ general term, $\rho=$ effect of block, $\alpha \mathrm{i}=$ effect of $\mathrm{i}^{\text {th }}$ treatments, $\varepsilon_{\mathrm{ij}}=$ error associated with $\mathrm{Y}_{\mathrm{ij}}$. The data were analyzed with analyses of variance (ANOVA) and were continued with orthogonal contrast test [8].

\subsubsection{Parameter Analyses}

Variables measured are: Cholesterol content of cooked goat milk with the method of Kleiner and Dotti [9]. Lipid content of cooked goat milk with the method of AOAC [10]. LDL (Low Density Lipoprotein) and HDL (High Density Lipoprotein) of cooked goat milk with the method by Assman [11]. Contents of linolenic fatty acid, linoleic fatty acid and unsaturated and saturated fatty acid cooked goat milk with the methods of AOAC [10].

\section{RESULTS AND DISCUSION}

\subsection{Lipids Content of Goat Milk}

The lowest lipids content of goat milk is treatment $\mathrm{P}_{4}$ with $3.757 \%$, whereas the highest lipids content is treatment $\mathrm{P}_{0}$ with $4.526 \%$. All data can be seen in Table 1.

Result of statistic orthogonal contrast revealed that content lipids of $\mathrm{P}_{0}$ significantly with $\mathrm{P}_{3}$ and $\mathrm{P}_{4}$. Treatment of $\mathrm{P}_{1}$ and $\mathrm{P}_{2}$ significantly with $\mathrm{P}_{3}$ and $\mathrm{P}_{4}$, whereas $\mathrm{P}_{3}$ non significant with $\mathrm{P}_{4}$. Content concentration of lipids non significantly with $\mathrm{P}_{2}$ with $\mathrm{P}_{1}$. Sudibya et al. [12] reported that supplementation of soya bean oil can not 
Table 1. Average concentration lipids, LDL, HDL and cholesterol of goat milk.

\begin{tabular}{ccccc}
\hline \multicolumn{5}{c}{ Parameter } \\
\hline Treatment & Content Lipids (\%) & Content LDL (mg/dl) & Content HDL (mg/dl) & Cholesterol (\%) \\
\hline $\mathrm{P}_{0}$ & $4.526^{\mathrm{a}}$ & $37.34^{\mathrm{a}}$ & $66.66^{\mathrm{a}}$ & $0.186^{\mathrm{a}}$ \\
$\mathrm{P}_{1}$ & $4.326^{\mathrm{a}}$ & $32.24^{\mathrm{a}}$ & $67.76^{\mathrm{a}}$ & $0.170^{\mathrm{a}}$ \\
$\mathrm{P}_{2}$ & $4.419^{\mathrm{a}}$ & $32.25^{\mathrm{a}}$ & $67.75^{\mathrm{a}}$ & $0.163^{\mathrm{a}}$ \\
$\mathrm{P}_{3}$ & $3.768^{\mathrm{b}}$ & $23.15^{\mathrm{b}}$ & $76.85^{\mathrm{b}}$ & $0.132^{\mathrm{b}}$ \\
$\mathrm{P}_{4}$ & $3.757^{\mathrm{b}}$ & $25.13^{\mathrm{b}}$ & $76.87^{\mathrm{b}}$ & $0.124^{\mathrm{b}}$ \\
\hline
\end{tabular}

Note: ${ }^{\mathrm{a}} \mathrm{P}<0.05$ and ${ }^{\mathrm{b}} \mathrm{P}<0.01$.

decreasing content lipid of dairy milk.

Supplementation lemuru fish oil of soap protected and tuna can decrease content lipids, because fish oil energy source and source content unsaturated fatty acids. Its can decrease content lipids of goat milks. Suarez et al. [13] reported that supplementation unsaturated in the ration can decrease content lipids in the body. For $\mathrm{P}_{3}$ non significantly with $\mathrm{P}_{4}$, because content lemuru fish oil and tuna fish oil is not significant influence.

\subsection{Content LDL (Low Density Lipoprotein) of Goat Milk}

Content LDL can be seen in Table 1. LDL (Low Density Lipoprotein ) the lowest content of LDL dairy milk is treatment $\mathrm{P}_{4} 25.13 \mathrm{mg}$ per $\mathrm{dl}$, whereas the highest content of LDL dairy milk is treatment $\mathrm{P}_{0} 37.34 \mathrm{mg}$ per $\mathrm{dl}$. All data can be seen in Table $\mathbf{1}$.

Result statistic of orthogonal contrast revealed that content LDL of $\mathrm{P}_{0}$ significantly with $\mathrm{P}_{2}, \mathrm{P}_{3}$ and $\mathrm{P}_{4}$. For $\mathrm{P}_{1}$ and $\mathrm{P}_{2}$ significantly with $\mathrm{P}_{3}$ and $\mathrm{P}_{4}$, whereas $\mathrm{P}_{3}$ non significant with $\mathrm{P}_{4}$. Content concentration LDL non significantly between $\mathrm{P}_{2}$ with $\mathrm{P}_{1}$. Sudibya et al. [14] reported that supplementation of soya bean oil can not decreasing content LDL of dairy milk.

Supplementation lemuru fish oil of soap protected and tuna can decrease content LDL, because fish oil energy source and source content unsaturated fatty acids. It can decrease content LDL of dairy milks. Kempen et al. [15] reported supplementation unsaturated in the ration can decreasing content LDL in the body experiment animal. For $\mathrm{P}_{3}$ non significantly with $\mathrm{P}_{4}$, because content lemuru fish oil as same as fish oil tuna it is not significant influence.

\subsection{Content HDL (High Density Lipoprotein) of Goat Milk}

Content HDL can be seen in Table 1. HDL (High Density Lipoprotein ), the highest content of HDL goat milk is $\mathrm{P}_{4} 76.87 \mathrm{mg}$ per dl, whereas the lowest content HDL is $\mathrm{P}_{0} 66.66 \mathrm{mg}$ per dl. All data can be seen in Table
1.

Result statistic orthogonal contrast revealed that content HDL of $\mathrm{P}_{0}$ significantly with $\mathrm{P}_{2}, \mathrm{P}_{3}$ and $\mathrm{P}_{4}$. For $\mathrm{P}_{1}$ and $\mathrm{P}_{2}$ significantly with $\mathrm{P}_{3}$ and $\mathrm{P}_{4}$, whereas $\mathrm{P}_{3}$ non significant with $\mathrm{P}_{4}$. Content concentration HDL is non significant between $\mathrm{P}_{2}$ and $\mathrm{P}_{1}$. Sudibya et al. [12] reported that supplementation of soya bean oil can not increase content HDL of dairy milk.

Supplementation lemuru fish oil of soap protected and tuna can increase content HDL, because fish oil energy source and source content unsaturated fatty acids. It can increase content HDL of goat milks. Kempen et al. [15] reported that supplementation unsaturated in the ration can increase content HDL in the body experiment animal.

\subsection{Content Cholesterol of Goat Milk}

The lowest content of cholesterol in goat milk is 0.124 in $\mathrm{P}_{4}$ treatment, while the highest is $0.186 \%$ in the $\mathrm{P}_{0}$. Data can be seen in Table 1. Statistical analysis showed that supplementation with tuna fish oil and fish oil protected lemuru significantly $(\mathrm{P}<0.01)$ decreasing cholesterol of goat milk. In order test of orthogonal contrast showed that cholesterol on $\mathrm{P}_{0}, \mathrm{P}_{1}$ and $\mathrm{P}_{2}$ significant than $\mathrm{P}_{3}$ and $\mathrm{P}_{4}$. Furthermore, $\mathrm{P}_{1}$ and $\mathrm{P}_{2}$ different very significant with $\mathrm{P}_{3}$, while $\mathrm{P}_{3}$ insignificantly different with $\mathrm{P}_{4}$. Cholesterol content of goat milk plus L-carnitine $\left(\mathrm{P}_{1}\right)$ did not decrease when compared to $\left(\mathrm{P}_{0}\right)$ in line with the opinion [16] which states that L-carnitine supplementation can be used to decrease cholesterol levels lamb, this is in line with the opinion of Owen et al. [1] that L-carnitine supplementation have function among others to decrease cholesterol content in the product. Besides the addition of soap being protected from tuna fish oil and lemuru fish oil can decrease cholesterol content of goat milk in $\mathrm{P}_{3}$ and $\mathrm{P}_{4}$, it concurred with Sudibya et al. $[3,4,17]$ that cholesterol levels in cattle beef and goat meat and milk of dairy cows decrease due to the transfer of omega-3 fatty acids, this can be explained that the omega-3 fatty acids work by stimulating the catabolism 
of HDL cholesterol to the liver back into bile acids and not regenerated again but released with excreta, so that the cholesterol content in excreta increased due to further deposition of cholesterol levels in sheep meat is reduced. Furthermore, insignificantly different $\mathrm{P}_{3}$ and $\mathrm{P}_{4}$, this is caused by the soap content of unsaturated fatty acids protected between lemuru fish oil with tuna fish oil is relatively the same so that different effects may seem unreal.

\subsection{Content of Omega-3 Fatty Acids (Linolenic) of Goat Milk}

Content of omega-3 fatty acids is highest in the $\mathrm{P}_{4}$ treatment $3.94 \%$ while the lowest was $1.00 \%$. Furthermore, it can be seen in Table 2, statistical analysis showed that supplementation with tuna fish oil soap and lemuru fish oil protected very significantly $(\mathrm{P}<0.01)$ on levels of omega-3 fatty acids of goat milk. In order test of orthogonal contrasts showed that levels of omega fatty acids of goat milk on $\mathrm{P}_{0}, \mathrm{P}_{1}$ and $\mathrm{P}_{2}$ significant than $\mathrm{P}_{3}$ and $\mathrm{P}_{4}$. Furthermore, $\mathrm{P}_{2}$ significant than $\mathrm{P}_{3}$ and $\mathrm{P}_{4}$, but insignificantly different $\mathrm{P}_{3}$ than $\mathrm{P}_{4}$. Suplementation L-carnitine $\left(\mathrm{P}_{1}\right)$ does not increase when compared to the $\mathrm{P}_{0}$ in line with the opinion of Owen et al. [1] which states that L-carnitine supplementation can not be used to increase levels of acid omega-3 because L-carnitine itself does not contain omega-3 fatty acid. The addition of protected lemuru fish oil and protected tuna oil can increase the content of omega-3 fatty acids of goat milk, as evidenced in the $\mathrm{P}_{3}$ and $\mathrm{P}_{4}$, this is because both these protected fish oil soaps contain unsaturated fatty acids. Furthermore, insignificantly different $\mathrm{P}_{3}$ than $\mathrm{P}_{4}$, this is caused by the content of unsaturated fatty acids in lemuru fish oil with tuna fish oil is relatively the same so that its influence does not seem different. In addition, fish oil supplementation protected soap to raise the content of omega-3 fatty acids, this can be explained other than oil as an energy source can also be a source of unsaturated fatty acids so as to raise the level of omega-3

Table 2. Average content omega- 3 and omega- 6 fatty acids of goat milk.

\begin{tabular}{ccc}
\hline \multicolumn{2}{c}{ Parameter } \\
\hline Treatment & Content omega-3 (\%) & Content omega-6 (\%) \\
\hline $\mathrm{P}_{0}$ & $1.00^{\mathrm{a}}$ & $1.46^{\mathrm{a}}$ \\
$\mathrm{P}_{1}$ & $1.21^{\mathrm{a}}$ & $1.97^{\mathrm{a}}$ \\
$\mathrm{P}_{2}$ & $1.67^{\mathrm{a}}$ & $3.71^{\mathrm{a}}$ \\
$\mathrm{P}_{3}$ & $3.92^{\mathrm{b}}$ & $18.79^{\mathrm{b}}$ \\
$\mathrm{P}_{4}$ & $3.94^{\mathrm{b}}$ & $18.80^{\mathrm{b}}$ \\
\hline
\end{tabular}

Note: ${ }^{\mathrm{a}} \mathrm{P}<0.05$ and ${ }^{\mathrm{b}} \mathrm{P}<0.01$. fatty acids of goat milk. This is in line with the opinion of Suarez et al. [13] which states that the omega-3 supplementation in the diet influence the concentration of omega-3 fatty acids in body tissue.

Furthermore, when compare to research Sudibya et al. $[3,4]$ which states that the content of omega- 3 fatty acids in beef cattle supplemented with lemuru fish oil of $5.92 \%$ and $5.96 \%$ for goat meat, in this study over a slightly higher value but still with in normal limits. Constantly, that are considered by the experts are usually ratio between omega- 3 fatty acids and omega- 6 . In this study turned out to have a ratio $6.46 \%$ (1) with $30.64 \%$ $(5,0)$. This is supported by Newton [18] that the recommendations of WHO and FAO have a ratio of omega-3 and omega- 6 of 1:5.

\subsection{Content of Omega-6 Fatty Acids (Linoleic) of Goat Milk}

Content of omega- 6 fatty acids is highest in the $\mathrm{P}_{4}$ treatment $18.86 \%$ while the lowest is $1.46 \%$. Furthermore, it can be seen in Table 2, statistical analysis showed that supplementation of tuna fish oil soap and lemuru fish oil protected high significantly $(\mathrm{P}<0.01)$ on contents of omega- 6 fatty acids of goat milk. In order test orthogonal contrast showed that content of omega- 6 fatty acids of goat milk on $\mathrm{P}_{0}, \mathrm{P}_{1}$ and $\mathrm{P}_{2}$ significant than $\mathrm{P}_{3}$ and $\mathrm{P}_{4}$. Furthermore, $\mathrm{P}_{2}$ significant than $\mathrm{P}_{3}$ and $\mathrm{P}_{4}$, but insignificantly different $\mathrm{P}_{3}$ than $\mathrm{P}_{4}$. Suplementation L-carnitine $\left(\mathrm{P}_{1}\right)$ does not increase when compared to the $\mathrm{P}_{0}$, in line with the opinion of Owen et al. [1] which states that L-carnitine supplementation can not be used to increase contents of fatty acid omega- 6 because L-carnitine itself does not contain omega- 6 fatty acid. The addition of protected lemuru fish oil and protected tuna oil to increase the content of omega- 6 fatty acids of goat milk, as evidenced in the $\mathrm{P}_{3}$ and $\mathrm{P}_{4}$, this is because both these protected fish oil soaps contain unsaturated fatty acids. Furthermore, insignificantly different $\mathrm{P}_{3}$ than $\mathrm{P}_{4}$, this is caused by the content of unsaturated fatty acids in lemuru fish oil with tuna fish oil is relatively the same so that it's influence does not seem different. In addition, fish oil supplementation protected soap can raise the content of omega- 6 fatty acids, this can be explained other than oil as an energy source can also be a source of unsaturated fatty acids so as to raise the level of omega- 6 fatty acids of goat milk. This is in line with the opinion of Suarez et al. [13] which states that the omega-6 supplementation in the diet affects the concentration of omega- 6 fatty acids in body tissue.

\section{CONCLUSION AND IMPLICATION}

\subsection{Conclusion}

Transfer of PUFA fatty acid protected of the diet con- 
taining 200 ppm L-carnitine can decrease milk cholesterol from $0.186 \%$ to $0.124 \%$, LDL from 33.34 to 23.13 $\mathrm{mg} / \mathrm{dl}$, lipid from $4.526 \%$ to $3.757 \%$, but it can increase omega-3 fatty acid from $1.00 \%$ to $3.94 \%$ and omega- 6 fatty acid from $1.46 \%$ to $18.80 \%$. This study has proofed how to reduce milk cholesterol and increase omega-3 fatty acids in the milk dairy goat. The effort to increase the content of omega-3 fatty acids and low cholesterol in the goat milk is a breakthrough to produce healthy animal products.

\subsection{Implication}

Transfer of PUFA fatty acid protected of the diet containing 200 ppm L-carnitine up to level $4 \%$ of the diet is recommended to reduce milk cholesterol and to increase omega-3 fatty acids in the milk dairy goat. This product could increase the quality of milk, so that could improve the health of milk dairy goat.

\section{REFERENCES}

[1] Owen, J.L., Nelssen, R.D., Goodband, Weeden, T.L. and Blum, S.A. (1996) Effects of L-carnitine and soyabean oil growth performance and body composition of early weaned pigs. Journal Animal Science, 74, 1612-1619.

[2] Sudibya, S., Sutardi, T.R., Soeprapto, H. and Dwi, Y. (2003) Low cholesterol beef poduction rich omega-3 fatty acids and organic fertilizer with EM-4 in group martini Indah district purwodadi. Project Development and Project Technology Upgrading Program Iptekda VI, University Research Institute of General Sudirman, Purwokerto.

[3] Sudibya, S. and Pratiknyo, H. (2006) Beef quality improvement flesh transfer through omega-3 capsulation and tape bran and organic fertilizer production by gama95 starter beef cattle in group "Sidamaju” in Bantul district. Project Development and Project Technology Upgrading Program Iptekda IX, Djenderal Soedirman University, Purwokerto.

[4] Sudibya, Widyastuti, T. and Santoso, S.S. (2007) Through the transfer of omega-3 and L-carnitine capsulilation its effect on chemical composition of goat meat. Competitive Grants Research Reports IX, Djenderal Soedirman University, Purwokerto.

[5] Chillard, Y. (1993) Dietary fat and metabolism in ruminant adipose tissue, pigs and rodents: A review. Journal of Dairy Science, 76, 3897-3931. doi:10.3168/jds.S0022-0302(93)77730-9
[6] Cherian, G. and Sim, J.S. (1992) Preferential accumulation of n-3 fatty acids in the brain of chicks from eggs enriched with n-3 fatty acids. Poultry Science, 71, 16581668. http://dx.doi.org/10.3382/ps.0711658

[7] Sudibya, S. and Martatmo, P. (2010) Bran fermentation technology and transfer of omega-3 protected influence on the content of linolenic acid, conjugated linoleic and arachidonic on milk cow dairy. Research Report SINTA, Sebelas Maret University, Surakarta.

[8] Steel, R.G.D. and Torrie, J.H. (1980) Principles and prosedures of statistics. Mc Graw-Hill Inc., New York. Toronto, London.

[9] Kleiner, I.S. and Dotti, L.B. (1962) Laboratory instructions in biochemistry. 6th Edition, The C.V. Mosby Company, New York.

[10] AOAC (1990) Official methods of analysis of the association of official analytical chemists. Association of Official Analytical Chemist, Washington, DC.

[11] Assman, G. (1982) Lipid metabolism and atherosclerosis Schattaver. Stuffgart Verlag.

[12] Sudibya, D. and Martatmo, P. (2009) Through the transfer of omega-3 and l-carnitine capsulation its effect on the chemical composition of milk of dairy cows. Report of Research Grants National Strategy Sets, Sebelas Maret University, Surakarta.

[13] Suarez, A.M., Ramires, D.C., Faus, M.J. and Gil, A. (1996) Dietary long-chain polyunsaturated fatty acids influence tissue fatty acid composition in Rats at weaning. Journal of Nutrition, 126, 887-897.

[14] Sudibya, Prabowo, D. and Hartoko (2004) Cellulase enzyme extract supplementation and unsaturated fatty acids in the basic ration of the quality and quantity of unsaturated fatty acid eggs. Scientific Journal, 30, 20-25.

[15] Kempen, T.A., Van, T.G. and Odle, J. (1995) Carnitine effects octanoat oxidation to carbondioxide and dicerboxylic acids in colostrum-deprived piglets: In vivo analysis of Mechanisms involved based on CoA and carnitine ester profiles. Journal of Nutrition, 125, 238-250.

[16] Sudibya (2005) Precursor supplementation with carnitine and L-carnitine on the tuna fish oil and cholesterol and unsaturated fatty acids duck eggs tegal. Djenderal Soedirman University, Purwokerto.

[17] Sudibya (2004) Chicken egg quality improvement through L-carnitine supplementation and tuna fish oil levels of omega-3 fatty acids, omega- 6 , omega-9 and cholesterol levels. Research Report, Unsoed Research Institute, Purwokerto.

[18] Newton, I.S. (1996) Food enricment with long-chain n-3 PUFA. INFORM, 7, 169-171. 